\section{The effects of fuel type on control rod reactivity of pebble-bed reactor}

Zuhair, Suwoto, Topan Setiadipura, Jim C. Kuijper

\begin{abstract}
As a crucial core physics parameter, the control rod reactivity has to be predicted for the control and safety of the reactor. This paper studies the control rod reactivity calculation of the pebble-bed reactor with three scenarios of $\mathrm{UO}_{2},(\mathrm{Th}, \mathrm{U}) \mathrm{O}_{2}$, and $\mathrm{PuO}_{2}$ fuel type without any modifications in the configuration of the reactor core. The reactor geometry of HTR-10 was selected for the reactor model. The entire calculation of control rod reactivity was done using the MCNP6 code with ENDF/B-VII library. The calculation results show that the total reactivity worth of control rods in $\mathrm{UO}_{2^{-}},(\mathrm{U}, \mathrm{Th}) \mathrm{O}_{2^{-}}$, and $\mathrm{PuO}_{2}$-fueled cores is $15.87,15.25$, and $14.33 \% \Delta k / k$, respectively. These results prove that the effectiveness of total control rod in thorium and uranium cores is almost similar to but higher than that in plutonium cores. The highest reactivity worth of individual control rod in uranium, thorium and plutonium cores is $1.64,1.44$, and $1.53 \% \Delta k / k$ corresponding to CR8, CR1, and CR5, respectively. The other results demonstrate that the reactor can be safely shutdown with the control rods combination of $\mathrm{CR} 3+\mathrm{CR} 5+\mathrm{CR} 8+\mathrm{CR} 10, \mathrm{CR} 2+\mathrm{CR} 3+\mathrm{CR} 7+\mathrm{CR} 8$, and $\mathrm{CR} 1+\mathrm{CR} 3+\mathrm{CR} 6+\mathrm{CR} 8$ in $\mathrm{UO}_{2-}$, (U,Th) $\mathrm{O}_{2^{-}}$, and $\mathrm{PuO}_{2}$-fueled cores, respectively. It can be concluded that, even though the calculation results are not so much different, however, the selection of control rods should be considered in the pebble-bed core design with different scenarios of fuel type.
\end{abstract}

Keywords: fuel type $\bullet$ control rod reactivity $\bullet$ pebble-bed reactor $\bullet$ MCNP6 $\bullet$ ENDF/B-VII

Zuhair $\bowtie$, Suwoto, T. Setiadipura

Center for Nuclear Reactor Technology and Safety

National Nuclear Energy Agency of Indonesia (BATAN)

Puspiptek Area, Office Building No. 80, Serpong

Tangerang Selatan 15310, Indonesia

E-mail: zuhair@batan.go.id

J. C. Kuijper

NUCLIC - Nuclear Innovation Consultancy

Iepenlaan 129 - 1741TD Schagen, The Netherlands

Received: 23 April 2019

Accepted: 4 September 2019

\section{Introduction}

The depletion of fossil energy and the negative effects of the accelerated consumption of fossil fuels in the environment in the last decade are particularly worrying. On the other hand, the world's energy needs are increasing significantly along with the increase in living standard of the world's population [1]). Not only reliable and cost-effective energy supply is needed but also safe and clean. To minimize the world's reliance on fossil fuels, nuclear energy proven as superiority in quantity of resources and compatibility with environment is expected to play an important role in fulfilling the future world energy demand.

Thirteen countries and research institutions in the world have been collaborating in the Generation IV International Forum (GIF), which is in charge of increasing the role of nuclear energy system in the future [2]. Generation IV reactors with the characteristics of high safety, minimal radioactive waste, and proliferation resistance are planned to start operation in 2030 [3). Pebble-bed reactor is one of the most promising Generation IV reactor design concepts because of its inherent safety characteristics and high coolant temperature. Inherent safety characteristic ensures the reactor capability 
of removing decay heat in all accident scenarios by a passive means only, and core meltdown is not likely to happen. The core outlet temperature is designed close to $1000^{\circ} \mathrm{C}$, which makes the pebble-bed reactor ideal for producing both electricity and process heat for hydrogen production [4]. The pebble-bed reactor is loaded with 10000 pebbles, where every pebble contains thousands of tristructural-isotropic (TRISO) particles dispersed in a graphite matrix and a layer of graphite shell. The TRISO particle comprising a fuel kernel and four coating layers has the capacity for effectively retaining the nuclear fuel, fission products, and actinides for temperatures up to $1600^{\circ} \mathrm{C}$.

In a nuclear reactor, the control rod system is designed to provide the control of core reactivity and the ability to shut down the reactor. Some chemical elements such as boron (B), silver (Ag), indium (In), and cadmium $(\mathrm{Cd})$ are often chosen as a control rod material because of their capability to absorb many neutrons. Hafnium (Hf), erbium (Er), and gadolinium $(\mathrm{Gd})$ are among the important neutron absorbers used to control the fission reactions in a nuclear reactor. Other absorber materials are being researched for commercial use including dysprosium titanate, hafnium diboride $\left(\mathrm{Hf}_{2} \mathrm{Br}\right)$, gadolinia, and europia [5]. Ag-In-Cd alloy is one of quite popular control rod absorber materials in pressurized-water reactor (PWR) designs with a sufficiently high neutron capture cross-section. The capture cross-section of the absorber material is based on neutron energy; therefore, the composition of the control rods must be designed for neutron spectrum of the reactor. The pebble-bed reactor that operates with thermal neutron uses the $\mathrm{B}_{4} \mathrm{C}$ alloy as a strong neutron absorber.

As a crucial core physics parameter, the control rod reactivity has to be predicted for the control and safety of the reactor. This paper studies the control rod reactivity calculation of pebble-bed reactor with different fuel scenarios. Three scenarios of $\mathrm{UO}_{2}$, (Th, $\mathrm{U}) \mathrm{O}_{2}$, and $\mathrm{PuO}_{2}$ fuel type are accommodated without any modifications in the configuration of the reactor core. The reactor geometry of HTR-10 was selected for the reactor model in this study [6]. Several stages starting from modeling of fuel pebble, reactor core, and reactor structural components consisting of graphite reflector and other reactor geometry such as carbon layer around the system, helium channels, small absorber balls, and modeling of the control rods were performed in detail and explicitly. The entire calculation of control rod reactivity was done using Monte Carlo transport code MCNP6 with the continuous energy nuclear data libraries ENDF/B-VII $[7,8]$. MCNP6 is the latest version of MCNP combining the MCNP5 and MCNPX to build new and more powerful capabilities. The results of control rod worth were then investigated to analyse the comparison of control rods' effectiveness in the reactor core with different fuel scenarios.

\section{HTR-10 pebble-bed reactor}

The HTR-10 is a pebble-bed reactor using helium as its coolant and graphite as the moderator with a nominal thermal power of $10 \mathrm{MW}$. The location of the reactor is at the Institute of Nuclear Energy Technology (INET), Tsinghua University, Beijing, China. HTR-10 is well known as the only currently operating pebble-bed reactor in the world. The first criticality was achieved on December 1, 2000. The core design was made with the combination of Arbeitsgemeinschaft Versuchsreaktor (AVR) and HTR-modul technologies. The main purpose of the HTR-10 reactor is to verify the inherent safety feature of the modular high-temperature gas-cooled reactor (HTGR) and to demonstrate its ability to produce electricity and process heat for industrial applications.

The HTR- 10 core with a diameter of $180 \mathrm{~cm}$ and a height of $197 \mathrm{~cm}$ is loaded with a mixture of fuel and moderator pebbles in a 57:43 ratio, respectively. There is a $26 \mathrm{~cm}$ cavity above the core. The pebbles are distributed randomly in the core with a packing fraction of 0.61 . The pebbles are loaded into the core from the top of the core using a loading fuel pipe. They move down the reactor and are discharged from the unloading pipe of the core bottom. The bottom of the pebble bed is a cone-shaped region initially consisting of moderator pebbles only. The fuel management in the core utilizes a multi-pass scheme where each fuel pebble passes through the reactor core five times before it reaches the burnup target. The fuel that has reached the burnup target is removed as waste for further processing.

Graphite, as the main structural material of the reactor, is used for the top, bottom, and side reflectors. In the inner side of the reflector, there are ten control rod channels, seven elliptical small absorber ball channels, and three experimental channels. In the outer side of the reflector, there are 20 helium flow channels. The helium with a temperature of $250^{\circ} \mathrm{C}$ flows through the space between pebbles in the core from the top to bottom, and it is heated up to a temperature of $700^{\circ} \mathrm{C}$. From the core, the helium flows to the steam generator and comes back up to the reactor core through helium channels in

Table 1. Main characteristics of HTR-10 reactor [9]

Reactor parameter

\begin{tabular}{lc}
\hline Thermal reactor power, $\mathrm{MW}$ & 10 \\
Inlet temperature of helium, ${ }^{\circ} \mathrm{C}$ & 250 \\
Outlet temperature of helium, ${ }^{\circ} \mathrm{C}$ & 700 \\
Helium pressure, $\mathrm{MPa}$ & 3 \\
Helium mass flow rate at full power, $\mathrm{kg} / \mathrm{s}$ & 4.3 \\
Number of control rods in side reflector & 10 \\
Number of small absorber balls in side & 7 \\
reflector & \\
\hline
\end{tabular}

Core specification

\begin{tabular}{lc}
\hline Core diameter, $\mathrm{cm}$ & 180 \\
Core height, cm & 197 \\
Number of fuel pebbles in core & 27000 \\
Fuel to moderator pebbles ratio & $57 / 43$ \\
Packing fraction of pebbles in the reactor & 0.61 \\
$\quad$ core & \\
Average burnup of discharged fuel pebbles, & 80000 \\
$\quad$ MWd/t &
\end{tabular}

Fuel loading scheme

Multi-pass 
Table 2. Plutonium isotopic vector

\begin{tabular}{lcc}
\hline & Isotope & Pu vector [\%] \\
\hline${ }^{238} \mathrm{Pu}$ & 2.59 \\
${ }^{239} \mathrm{Pu}$ & 53.85 \\
${ }^{240} \mathrm{Pu}$ & 23.66 \\
${ }^{241} \mathrm{Pu}$ & 13.13 \\
${ }^{242} \mathrm{Pu}$ & 6.77 \\
\hline
\end{tabular}

the side reflector. Helium is used as a coolant due to its thermal and chemical stability, good compatibility with the core graphite material, and metallic material of the primary system at a high temperature condition. The main characteristics of the HTR-10 reactor are given in Table 1.

The fuel pebble and moderator pebble of HTR-10 have the same diameter $(6 \mathrm{~cm})$ but different contents. The moderator pebble does not contain anything other than graphite. The fuel pebble consists of 15000 TRISO-coated fuel particles dispersed in the graphite matrix with a radius of $2.5 \mathrm{~cm}$, which is covered by a $0.5 \mathrm{~cm}$ thick graphite shell layer. This graphite acts as both a containment for the fuel particles and a moderator in addition to the moderator pebbles. Each TRISO particle contains a kernel and four coating layers wrapping the kernel: buffer graphite layer, inner layer of pyrocarbon (iPyC), layer of silicon carbide ( $\mathrm{SiC}$ ), and outermost layer of pyrocarbon (oPyC). Three scenarios of $\mathrm{UO}_{2}$, (Th, $\mathrm{U}_{2} \mathrm{O}_{2}$, and $\mathrm{PuO}_{2}$ fuel type are accommodated without any modifications in the configuration of the reactor core. Fuel kernels $\mathrm{UO}_{2}$ and $(\mathrm{Th}, \mathrm{U}) \mathrm{O}_{2}$ have enrichment by mass of the ${ }^{235} \mathrm{U}$ and ${ }^{233} \mathrm{U}$ being $8.20 \%$ and $7.49 \%$, respectively. The kernel $\mathrm{PuO}_{2}$ has a plutonium isotopic vector as given in Table 2 .

All fuel kernels have the same density of $10.4 \mathrm{~g} / \mathrm{cm}^{3}$, but different radii, namely, $0.025,0.025$, and $0.012 \mathrm{~cm}$ corresponding to $9.00 \mathrm{~g}$ uranium, $8.98 \mathrm{~g}$ thorium, and $1.00 \mathrm{~g}$ plutonium mass per fuel pebble, respectively. The coating thickness of $\mathrm{UO}_{2}$ and $(\mathrm{Th}, \mathrm{U}) \mathrm{O}_{2}$ is the same but a little bit different from that of $\mathrm{PuO}_{2}$. These coatings ensure the stabil-
Table 4. Specification of moderator pebbles

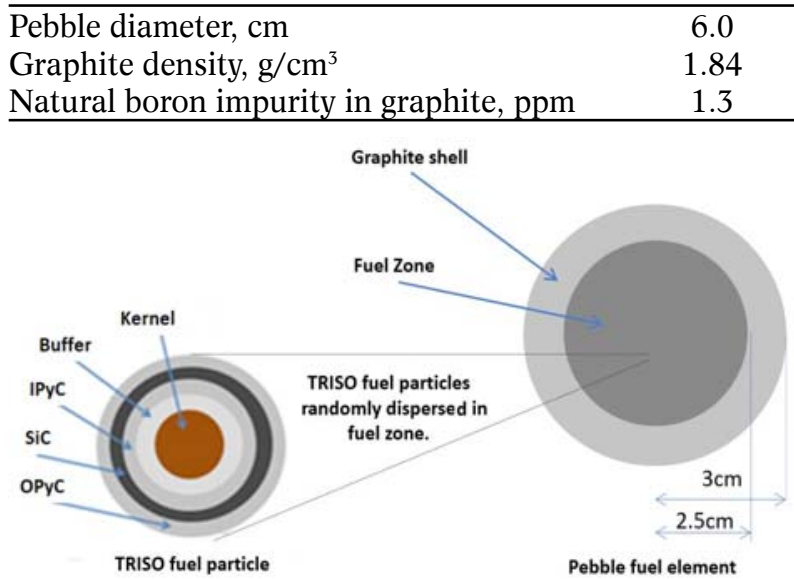

Fig. 1. Schematic view of the fuel pebble [11].

ity and integrity of the fuel structure and prevent all fission products from releasing to the environment under normal operating and any accident scenario conditions [10]. Tables 3 and 4 show the detailed specification of the fuel pebble and moderator pebble, respectively. The schematic view of the fuel pebble is illustrated in Fig. 1.

\section{Modeling of HTR-10}

The feature of the pebble-bed reactor is characterized by double heterogeneity nature consisting of the distribution of TRISO particles in the fuel pebbles as the first heterogeneity and the distribution of fuel pebbles in the reactor core as the second heterogeneity. The extremely large number of TRISO particles and fuel pebbles with their random positions makes it difficult to model a pebble-bed reactor exactly. The Monte Carlo transport code MCNP6 is one of the advanced computer codes that can solve this problem. In this study, the modeling of HTR-10 is divided into three categories: fuel pebble, reactor core, and control rod modeling.

Table 3. Specification of fuel pebble

Fuel pebble

\begin{tabular}{lclc}
\hline Pebble diameter, $\mathrm{cm}$ & 6.0 & Graphite shell density, g/cm & 1.73 \\
Fueled-zone diameter, cm & 5.0 & Natural boron impurity in graphite shell, ppm & 1.3 \\
Fuel mass per pebble, $\mathrm{g}$ & $9.00^{\text {(a) }}$ & Number of coated particle per pebble & 15000 \\
Graphite shell thickness, cm & 0.5 & Pebble packing fraction, \% & 61 \\
\hline
\end{tabular}

TRISO-coated particle

\begin{tabular}{|c|c|c|c|}
\hline Fuel kernel & & $\begin{array}{c}\text { Thickness } \\
{[\mu \mathrm{m}]}\end{array}$ & $\begin{array}{l}\text { Density } \\
{\left[\mathrm{g} / \mathrm{cm}^{3}\right]}\end{array}$ \\
\hline Kernel diameter, $\mathrm{cm}$ & $0.012^{(\mathrm{b})}$ & Buffer & \\
\hline Kernel density, $\mathrm{g} / \mathrm{cm}^{3}$ & 10.4 & $90^{\text {(d) }}$ & 1.14 \\
\hline Natural boron impurity in kernel, ppm & 4 & $\mathrm{iPyC} / \mathrm{oPyC}$ & \\
\hline Graphite matrix density, $\mathrm{g} / \mathrm{cm}^{3}$ & 1.73 & 40 & 1.89 \\
\hline $\begin{array}{l}\text { Natural boron impurity in graphite } \\
\text { matrix, ppm }\end{array}$ & 1.3 & $\mathrm{SiC}$ & \\
\hline TRISO packing fraction, $\%$ & $9.043^{(\mathrm{c})}$ & 35 & 3.20 \\
\hline
\end{tabular}

$\begin{array}{lllll}\text { (a) } 1.00 \text { and } 8.98 \text { for } \mathrm{PuO}_{2} \text { and }(\mathrm{Th}, \mathrm{O}) \mathrm{O}_{2} \text { fuels, respectively. } & \text { (b) } 0.012 \text { for } \mathrm{PuO}_{2} \text { fuel. } & \text { (c) } 3.45 \text { for } \mathrm{PuO}_{2} \text { fuel. } & \text { (d) } 95 \text { for }\end{array}$ $\mathrm{PuO}_{2}$ fuel. 


\section{Modeling of fuel pebble}

The modeling of fuel pebble was begun by representing the TRISO particle in a unit cell of simple cubic (SC) lattice. The TRISO particle was placed in the lattice center with the graphite matrix occupying the remaining volume of the lattice. The TRISO density and dimension were exact. A lattice pitch of $0.163430 \mathrm{~cm}$ was calculated to get exactly 15000 TRISO particles distributed in the fuel pebble. The modeling of fuel pebble was used by expanding to the SC unit cell into the fueled zone. The repeated structure constructed by UNIVERSE and combination of LATTICE and FILL options was used in this modeling. The modeling of the fuel pebble became complete after constructing the graphite shell, which coated the fueled zone of the pebble.

\section{Modeling of reactor core}

Similar to the modeling of the fuel pebble, the modeling of the reactor core was begun by representing the fuel pebble in a unit cell of body center cubic (BCC) lattice. This lattice described two pebbles consisting of one fuel pebble in the center of the lattice and eight of $1 / 8$ moderator pebbles in the eight lattice corner. The helium coolant in the lattice occupied the empty space outside the pebbles. The radius of the fuel pebble was kept constant to consider the effect of the double heterogeneity.

The radius of the moderator pebble $\left(\mathrm{R}_{\mathrm{M}}\right)$ was changed from $3 \mathrm{~cm}$ to $2.805894 \mathrm{~cm}, 3.251120 \mathrm{~cm}$, and $2.805894 \mathrm{~cm}$ to preserve a mixture of $55 \%$ $\mathrm{UO}_{2}$ fuel (F) and $45 \%$ moderator pebbles (M), 44\% (Th,U) $\mathrm{O}_{2}$ fuel (F) and 56\% moderator pebbles (M), and $34 \% \mathrm{PuO}_{2}$ fuel (F) and $66 \%$ moderator pebbles $(\mathrm{M})$, respectively, using the following formula:

$$
\mathrm{R}_{\mathrm{M}}=\mathrm{R}_{\mathrm{F}} \cdot \sqrt[3]{\frac{\mathrm{M}}{\mathrm{F}}}
$$

where $R_{F}$ is the radius of the fuel pebble, $F$ is the amount of the fuel pebble, and $\mathrm{M}$ is amount of the moderator pebble.

To set pebble packing fraction $(f)$ of 0.61 unchanged, the lattice pitch $(a)$ was readjusted from $7.185259 \mathrm{~cm}$ to $6.960571 \mathrm{~cm}, 7.498048 \mathrm{~cm}$, and $8.170955 \mathrm{~cm}$ for $\mathrm{UO}_{2}$, (Th, $\left.\mathrm{U}\right) \mathrm{O}_{2}$, and $\mathrm{PuO}_{2}$ fuels, respectively, based on the following formula:

$$
a=\mathrm{R}_{\mathrm{F}} \cdot \sqrt[3]{\frac{4 \pi}{3 f}\left(1+\frac{\mathrm{M}}{\mathrm{F}}\right)}
$$

All these values were used to produce almost the same multiplication factors between three fuel types with all control rods in fully withdrawn condition.

The reactor core was modeled by expanding to the BCC unit cell using the repeated structure constructed by the UNIVERSE and combination of LATTICE and FILL options. This modeling procedure was used in various publications since it was introduced by Lebenhaft in 2001 [12-19].

Utilizing repeated structure produces some truncated TRISO particles on the fueled-zone surface of the pebble and some truncated pebbles on the boundary of the reactor core. In the modeling of the fuel pebble, the effect of repeated structure is not taken into account because it does not significantly influence the accuracy of the results. Moreover, the effect of pebble boundary can generally be ignored for the calculation of the pebble-bed core and is only important for the cell calculation [20]. However, in the modeling of reactor core, this effect has to be considered. A correction is made by applying the exclusion zone of helium with thicknesses of $1.65,1.32$, and $1.02 \mathrm{~cm}$ around the core for $\mathrm{UO}_{2}$, (Th,U) $\mathrm{O}_{2}$, and $\mathrm{PuO}_{2}$ fuels, respectively. The exclusion zone will automatically reduce the core volume, which is used to compensate for the contribution of truncated fuel and moderator pebbles at the boundary of the reactor core.

The modeling of reactor structural components consisting of graphite reflector and other reactor geometry such as carbon layer around the system, helium channels, and small absorber balls as one of reactor shutdown systems was performed in detail and explicitly. The cone-shaped region at the bottom of the reactor core filled with only moderator pebbles was easily modeled with a packing fraction of 0.61 . The MCNP6 modeling of the TRISO particle in the SC lattice and pebbles in the BCC lattice is illustrated in Fig. 2.

$\mathrm{a}$

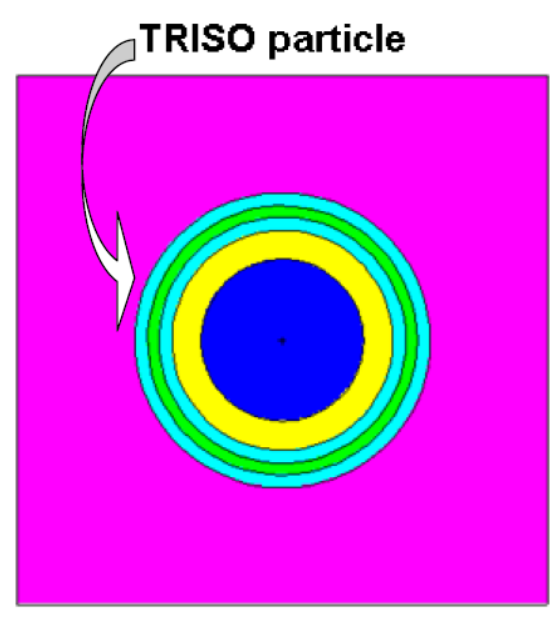

b

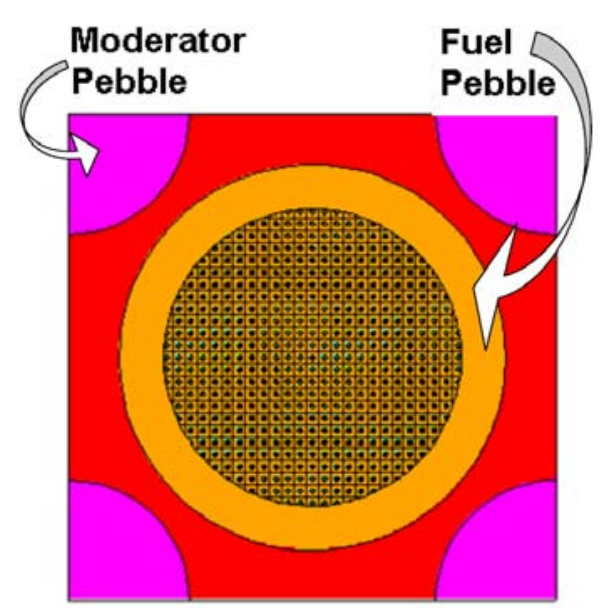

Fig. 2. The MCNP6 modeling of HTR-10 fuel and moderator pebbles. (a) SC lattice for TRISO particle. (b) BCC lattice for pebbles. 
Table 5. Design parameters of the control rod system

Average height of active core, $\mathrm{cm}$

Distance from control rod channel to center of reactor core, $\mathrm{cm}$

Diameter of control rod channel, $\mathrm{cm}$

Inner diameter of absorber, $\mathrm{cm}$

Outer diameter of absorber, $\mathrm{cm}$

Material of control rod absorber

Total effective length of control rod absorber

Control rod normal insertion speed, $\mathrm{cm} / \mathrm{s}$

Control rod emergency insertion time, $\mathrm{s}$

Control rod stroke, $\mathrm{cm}$

Medium

Pressure, $\mathrm{MPa}$

Temperature of control rod drive

mechanism, ${ }^{\circ} \mathrm{C}$

\section{Modeling of control rods}

Ten identical control rods in HTR-10 are located in ten channels in the side reflector in the vertical position and are uniformly distributed encircling the reactor core. This control rod system is designed to work at a high temperature and a high radiation and in the helium environment. The $\mathrm{B}_{4} \mathrm{C}$ with a density of $1.7 \mathrm{~g} / \mathrm{cm}^{3}$ composed of carbon of $20 \%$, boron -10 of $15.84 \%$, and boron- 11 of $64.16 \%$ is used as a neutron absorber. Each control rod has five $\mathrm{B}_{4} \mathrm{C}$ ring segments, which are housed in the area between an inner sleeve and an outer sleeve of stainless steel. These are then connected together by metallic joints. The inner and outer diameters of the $\mathrm{B}_{4} \mathrm{C}$ ring are $6.0 \mathrm{~cm}$ and $10.5 \mathrm{~cm}$, respectively, while the length of each ring segment is $48.7 \mathrm{~cm}$. The inner and outer diameters of the inner and outer stainless steel sleeves are $5.5 \mathrm{~cm}$ and $5.9 \mathrm{~cm}$ and of the outer stainless steel sleeve are $10.6 \mathrm{~cm}$ and $11.0 \mathrm{~cm}$, respectively. The length of each joint is $3.6 \mathrm{~cm}$. The lengths of the lower and upper metallic end are $4.5 \mathrm{~cm}$ and $2.3 \mathrm{~cm}$, respectively.

The insertion of control rods into channels as far as $275 \mathrm{~cm}$, which is greater than the height of the active core, can be done by means of gravity with a normal speed of $1 \mathrm{~cm} / \mathrm{s}$. The design parameters of the control rod system are given in Table 5 . The complexity of HTR-10 control rods geometry was modeled in

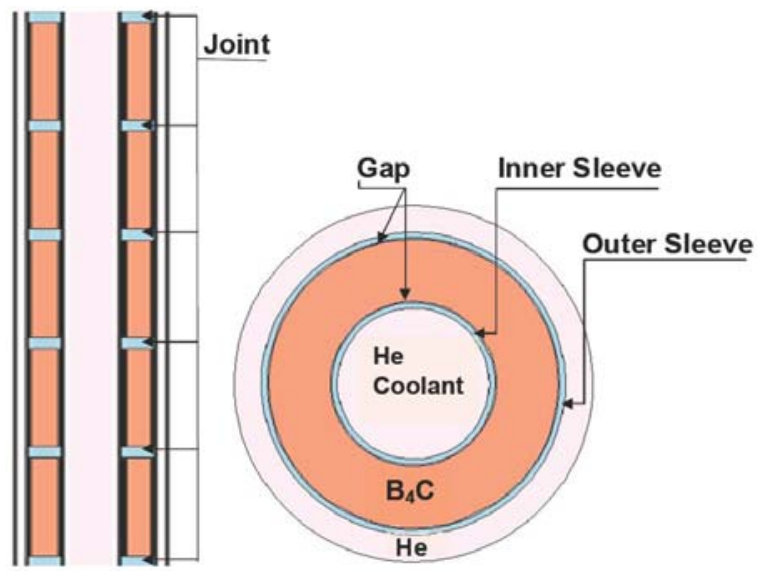

Fig. 3. The MCNP6 modeling of HTR-10 control rod. detail and explicitly with special treatment. Figure 3 illustrates the MCNP6 modeling of HTR-10 control rod. The MCNP6 modeling of HTR-10 pebble-bed reactor is illustrated in Fig. 4. This model has been verified through the MCNP6 benchmark model in the calculation of HTR-10 control rod reactivity in a good agreement with a previous study [21].

\section{Results and discussion}

The calculation of control rod reactivity was performed using 210 cycles of 5000 particles per cycle where 10 cycles were skipped to obtain sufficient accuracy. The initial neutron source is located at numerous points within the fuel pebble to reduce the convergence time of the source distribution. The ENDF/B-VII continuous energy nuclear data library was used for all calculations at room temperature of $300 \mathrm{~K}$. Thermal scattering library $S(\alpha, \beta)$ of grph.01t was applied to account the binding effect of the interaction between thermal neutron and graphite contained in each reactor material under energy of $4 \mathrm{eV}$. The isotopic concentration of TRISO particles is given in Table 6. The isotopic concentration of graphite matrix and graphite shell, which are identically used in all calculations, is given in Table 7.

a

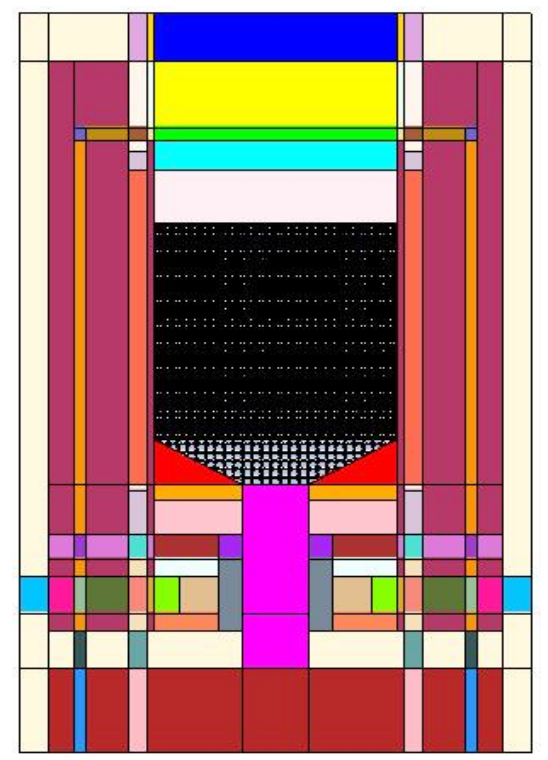

b

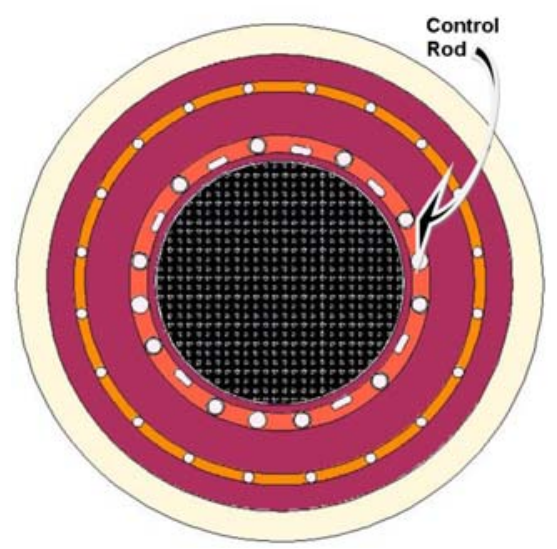

Fig. 4. The MCNP6 modeling of HTR-10 pebble-bed reactor. (a) Vertical view. (b). Horizontal view. 
Table 6. Isotopic concentration of TRISO particles in the fuel pebble (atom/barn-cm) [22]

\begin{tabular}{|c|c|c|c|}
\hline & Kernel $\mathrm{UO}_{2}$ & \multicolumn{2}{|c|}{ Kernel $(\mathrm{Th}, \mathrm{U}) \mathrm{O}_{2}$} \\
\hline$\overline{{ }^{238} \mathrm{U}}$ & $2.12877 \times 10^{-2}$ & ${ }^{232} \mathrm{Th}$ & $2.19473 \times 10^{-2}$ \\
\hline${ }^{235} \mathrm{U}$ & $1.92585 \times 10^{-3}$ & ${ }^{233} \mathrm{U}$ & $1.76668 \times 10^{-3}$ \\
\hline${ }^{16} \mathrm{O}$ & $4.64272 \times 10^{-2}$ & ${ }^{16} \mathrm{O}$ & $4.74279 \times 10^{-2}$ \\
\hline${ }^{10} \mathrm{~B}$ & $1.14694 \times 10^{-7}$ & ${ }^{10} \mathrm{~B}$ & $1.14694 \times 10^{-7}$ \\
\hline \multirow[t]{2}{*}{${ }^{11} \mathrm{~B}$} & $4.64570 \times 10^{-7}$ & ${ }^{11} \mathrm{~B}$ & $4.64570 \times 10^{-7}$ \\
\hline & Kernel $\mathrm{PuO}_{2}$ & & Buffer \\
\hline$\overline{{ }^{238} \mathrm{Pu}}$ & $6.01178 \times 10^{-4}$ & $\mathrm{C}$ & $5.26449 \times 10^{-2}$ \\
\hline${ }^{239} \mathrm{Pu}$ & $1.24470 \times 10^{-2}$ & \multicolumn{2}{|c|}{ iPyC/oPyC } \\
\hline${ }^{240} \mathrm{Pu}$ & $5.44599 \times 10^{-3}$ & $\mathrm{C}$ & $9.52621 \times 10^{-2}$ \\
\hline${ }^{241} \mathrm{Pu}$ & $3.00965 \times 10^{-3}$ & $\mathrm{SiC}$ & \\
\hline${ }^{242} \mathrm{Pu}$ & $1.54539 \times 10^{-3}$ & ${ }^{28} \mathrm{Si}$ & $4.39872 \times 10^{-2}$ \\
\hline${ }^{16} \mathrm{O}$ & $4.60983 \times 10^{-2}$ & ${ }^{29} \mathrm{Si}$ & $2.24780 \times 10^{-3}$ \\
\hline${ }^{10} \mathrm{~B}$ & $1.14694 \times 10^{-7}$ & ${ }^{30} \mathrm{Si}$ & $1.48899 \times 10^{-3}$ \\
\hline${ }^{11} \mathrm{~B}$ & $4.64570 \times 10^{-7}$ & $\mathrm{C}$ & $4.77240 \times 10^{-2}$ \\
\hline
\end{tabular}

Table 7. Isotopic concentration of graphite matrix and shell (atom/barn-cm) [22]

\begin{tabular}{lclc}
\hline & Graphite matrix & \multicolumn{2}{l}{ Graphite shell } \\
\hline $\mathrm{C}$ & $8.67417 \times 10^{-2}$ & $\mathrm{C}$ & $8.67417 \times 10^{-2}$ \\
${ }^{10} \mathrm{~B}$ & $2.24401 \times 10^{-8}$ & ${ }^{10} \mathrm{~B}$ & $2.24401 \times 10^{-8}$ \\
${ }^{11} \mathrm{~B}$ & $9.03242 \times 10^{-8}$ & ${ }^{11} \mathrm{~B}$ & $9.03242 \times 10^{-8}$ \\
\hline
\end{tabular}

The calculation results of total control rod reactivity are illustrated in Fig. 5. The calculation was performed at various insertion depths of control rods. All control rods are moved and inserted into the core step by step with an interval of $27.5 \mathrm{~cm}$ until they are fully inserted. It is found that the reactor can be safely shutdown in each scenario of fuel considered. The total reactivity worth of control rods in $\mathrm{UO}_{2-}$, (U,Th) $\mathrm{O}_{2-}$, and $\mathrm{PuO}_{2}$-fueled cores are 15.87, 15.25, and $14.33 \% \Delta k / k$, respectively. This means that the effectiveness of control rods in thorium and uranium cores is almost similar but higher than that in plutonium cores. These values are taken from the calculation results of the three fuel types based on the condition that all control rods are fully withdrawn. The calculations are made almost equal by adjusting the fuel and moderator pebble ratio in the core, namely, $1.06462 \pm 0.00084,1.06463 \pm 0.00079$, and $1.06465 \pm 0.00081$ for $\mathrm{UO}_{2^{-}},(\mathrm{U}, \mathrm{Th}) \mathrm{O}_{2^{-}}$, and $\mathrm{PuO}_{2}$-fueled cores, respectively.

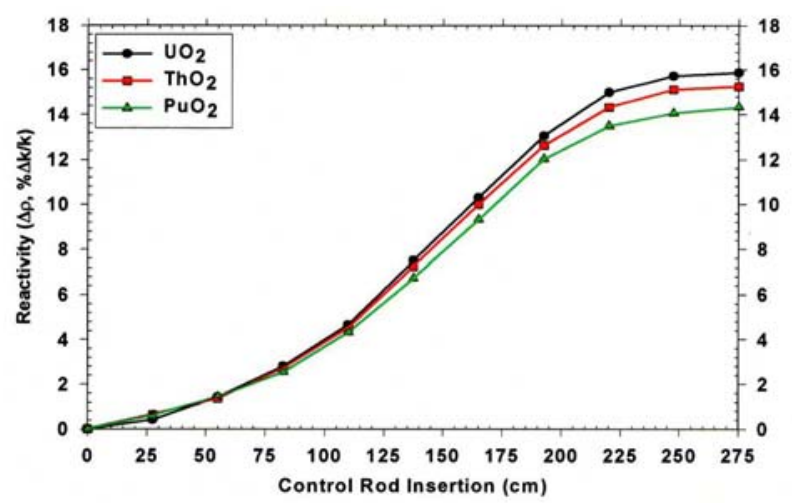

Fig. 5. The calculation results of total control rod reactivity worth.
The individual control rod worth in the reactor core is important to investigate the control rod that has the highest reactivity. The calculation was performed under the condition that all control rods are fully withdrawn except the one that is considered to be fully inserted. There were ten control rods in the core; therefore, the calculation was repeated ten times for each fuel type. The results are summarized in Table 8 . This table shows that the highest reactivity worth of individual control rod in uranium, thorium, and plutonium cores are 1.64, 1.44, and $1.53 \% \Delta k / k$ corresponding to CR8, CR1, and CR5, respectively. Control rods such as CR8, CR1, and CR5 are usually called as regulating rods. The regulating rod is a special control rod and its movement greatly affects the reactor core reactivity; therefore, the regulating rod must be identified.

The reactivity worth of several combinations of control rods was also calculated to investigate which one of the control rods combination has the highest value. A series of control rods combination was made by symmetrically arranging the regulating rod and other three control rods in the condition of fully inserted and the rest one in the condition of

Table 8. The reactivity worth of individual control rod

\begin{tabular}{|c|c|c|}
\hline $\begin{array}{l}\text { Control rod } \\
\text { (CR) }\end{array}$ & $k_{\text {eff }}$ & $\Delta \rho(\% \Delta k / k)$ \\
\hline & \multicolumn{2}{|c|}{$\mathrm{UO}_{2}$} \\
\hline$\overline{\mathrm{CR} 1}$ & $1.04766 \pm 0.00082$ & $-1.52 \pm 0.11$ \\
\hline CR2 & $1.04864 \pm 0.00083$ & $-1.43 \pm 0.11$ \\
\hline CR3 & $1.04715 \pm 0.00083$ & $-1.57 \pm 0.11$ \\
\hline CR4 & $1.04889 \pm 0.00083$ & $-1.41 \pm 0.11$ \\
\hline CR5 & $1.04851 \pm 0.00082$ & $-1.44 \pm 0.11$ \\
\hline CR6 & $1.04894 \pm 0.00094$ & $-1.40 \pm 0.11$ \\
\hline CR7 & $1.04854 \pm 0.00086$ & $-1.44 \pm 0.11$ \\
\hline CR8 & $1.04640 \pm 0.00089$ & $-1.64 \pm 0.11$ \\
\hline CR9 & $1.04700 \pm 0.00093$ & $-1.58 \pm 0.11$ \\
\hline \multirow[t]{2}{*}{ CR10 } & $1.04807 \pm 0.00077$ & $-1.48 \pm 0.10$ \\
\hline & \multicolumn{2}{|c|}{$(\mathrm{Th}, \mathrm{U}) \mathrm{O}_{2}$} \\
\hline$\overline{\mathrm{CR} 1}$ & $1.04856 \pm 0.00085$ & $-1.44 \pm 0.10$ \\
\hline CR2 & $1.04908 \pm 0.00081$ & $-1.39 \pm 0.10$ \\
\hline CR3 & $1.04986 \pm 0.00075$ & $-1.32 \pm 0.10$ \\
\hline CR4 & $1.04873 \pm 0.00088$ & $-1.42 \pm 0.11$ \\
\hline CR5 & $1.04976 \pm 0.00081$ & $-1.33 \pm 0.10$ \\
\hline CR6 & $1.05009 \pm 0.00083$ & $-1.30 \pm 0.10$ \\
\hline CR7 & $1.04939 \pm 0.00081$ & $-1.36 \pm 0.10$ \\
\hline CR8 & $1.04945 \pm 0.00086$ & $-1.36 \pm 0.10$ \\
\hline CR9 & $1.04891 \pm 0.00079$ & $-1.41 \pm 0.10$ \\
\hline \multirow[t]{2}{*}{ CR10 } & $1.04901 \pm 0.00080$ & $-1.40 \pm 0.10$ \\
\hline & \multicolumn{2}{|c|}{$\mathrm{PuO}_{2}$} \\
\hline$\overline{\mathrm{CR} 1}$ & $1.04890 \pm 0.00088$ & $-1.41 \pm 0.11$ \\
\hline CR2 & $1.04834 \pm 0.00079$ & $-1.46 \pm 0.10$ \\
\hline CR3 & $1.05014 \pm 0.00081$ & $-1.30 \pm 0.10$ \\
\hline CR4 & $1.04808 \pm 0.00087$ & $-1.48 \pm 0.11$ \\
\hline CR5 & $1.04763 \pm 0.00087$ & $-1.53 \pm 0.11$ \\
\hline CR6 & $1.04865 \pm 0.00081$ & $-1.43 \pm 0.10$ \\
\hline CR7 & $1.04949 \pm 0.00075$ & $-1.36 \pm 0.10$ \\
\hline CR8 & $1.04969 \pm 0.00086$ & $-1.34 \pm 0.11$ \\
\hline CR9 & $1.04969 \pm 0.00087$ & $-1.34 \pm 0.11$ \\
\hline CR10 & $1.04834 \pm 0.00085$ & $-1.46 \pm 0.11$ \\
\hline
\end{tabular}


Table 9. The reactivity worth of control rod combination

\begin{tabular}{|c|c|c|}
\hline Combination of control rod (CR) & $k_{\text {eff }}$ & $\Delta \rho(\% \Delta k / k)$ \\
\hline & \multicolumn{2}{|c|}{$\mathrm{UO}_{2}$} \\
\hline$\overline{\mathrm{CR} 1}+\mathrm{CR} 3+\mathrm{CR} 6+\mathrm{CR} 8$ & $0.99405 \pm 0.00078$ & $-6.67 \pm 0.11$ \\
\hline $\mathrm{CR} 2+\mathrm{CR} 3+\mathrm{CR} 7+\mathrm{CR} 8$ & $0.99942 \pm 0.00087$ & $-6.13 \pm 0.11$ \\
\hline $\mathrm{CR} 3+\mathrm{CR} 4+\mathrm{CR} 8+\mathrm{CR} 9$ & $1.00158 \pm 0.00090$ & $-5.91 \pm 0.12$ \\
\hline \multirow[t]{2}{*}{$\underline{\mathrm{CR} 3}+\mathrm{CR} 5$ + CR8 + CR10 } & $0.99397 \pm 0.00091$ & $-6.68 \pm 0.12$ \\
\hline & \multicolumn{2}{|c|}{$(\mathrm{Th}, \mathrm{U}) \mathrm{O}_{2}$} \\
\hline$\overline{\mathrm{CR} 1}+\mathrm{CR} 3+\mathrm{CR} 6+\mathrm{CR} 8$ & $1.00174 \pm 0.00095$ & $-5.90 \pm 0.12$ \\
\hline $\mathrm{CR} 2+\mathrm{CR} 3+\mathrm{CR} 7+\mathrm{CR} 8$ & $0.99759 \pm 0.00084$ & $-6.31 \pm 0.11$ \\
\hline $\mathrm{CR} 3+\mathrm{CR} 4+\mathrm{CR} 8+\mathrm{CR} 9$ & $0.99795 \pm 0.00087$ & $-6.28 \pm 0.11$ \\
\hline \multirow[t]{2}{*}{$\mathrm{CR} 3$ + CR5 + CR8 + CR10 } & $1.00351 \pm 0.00082$ & $-5.72 \pm 0.11$ \\
\hline & \multicolumn{2}{|c|}{$\mathrm{PuO}_{2}$} \\
\hline$\overline{\mathrm{CR} 1+\mathrm{CR} 2+\mathrm{CR} 6+\mathrm{CR} 7}$ & $1.00474 \pm 0.00088$ & $-5.60 \pm 0.11$ \\
\hline $\mathrm{CR} 1+\mathrm{CR} 3+\mathrm{CR} 6+\mathrm{CR} 8$ & $0.99980 \pm 0.00084$ & $-6.09 \pm 0.11$ \\
\hline $\mathrm{CR} 1+\mathrm{CR} 4+\mathrm{CR} 6+\mathrm{CR} 9$ & $1.00103 \pm 0.00090$ & $-5.97 \pm 0.11$ \\
\hline$\underline{\mathrm{CR} 1}+\mathrm{CR} 5$ + CR6 + CR10 & $1.00407 \pm 0.00076$ & $-5.67 \pm 0.10$ \\
\hline
\end{tabular}

fully withdrawn. The calculation results are shown in Table 9. This table represents that the combination of CR3 + CR5 + CR8 + CR10 has the highest reactivity worth in $\mathrm{UO}_{2}$-fueled core. Similarly, the combination of $\mathrm{CR} 2+\mathrm{CR} 3+\mathrm{CR} 7+\mathrm{CR} 8$ and the combination of $\mathrm{CR} 1+\mathrm{CR} 3+\mathrm{CR} 6+\mathrm{CR} 8$ indicate the highest reactivity worth in $(\mathrm{Th}, \mathrm{U}) \mathrm{O}_{2}$ - and $\mathrm{PuO}_{2}$-fueled cores, respectively. These results demonstrate that the reactor can be safely shutdown, especially with four control rods whose combinations produce the highest reactivity worth.

\section{Conclusion}

The effect of fuel type on control rod reactivity of the pebble-bed reactor has been investigated and analysed. The total reactivity worth of control rods in $\mathrm{UO}_{2^{-}}$, (U,Th) $\mathrm{O}_{2^{-}}$, and $\mathrm{PuO}_{2}$-fueled cores is $15.87,15.25$, and $14.33 \% \Delta k / k$. This proves that the effectiveness of total control rod in thorium and uranium cores is almost similar but higher than that in plutonium cores. The highest reactivity worth of individual control rod in uranium, thorium, and plutonium cores is $1.64,1.44$, and $1.53 \% \Delta k / k$ corresponding to CR8, CR1, and CR5, respectively. The other results demonstrate that the reactor can be safely shutdown with the control rods combination of CR3+CR5+CR8+CR10, CR2 + CR3+CR7+CR8, and CR1+CR3+CR6+CR8 in $\mathrm{UO}_{2-}^{-},(\mathrm{U}, \mathrm{Th}) \mathrm{O}_{2-}$, and $\mathrm{PuO}_{2}$-fueled cores, respectively. It can be concluded that even though the calculation results are not so much different, however, the selection of control rod should be considered in the pebble-bed core design with different scenarios of fuel type.

Acknowledgment. We would like to express our sincere gratitude to Dr. Geni Rina Sunaryo for her motivation and support in conducting this research. We would also like to thank Syaiful Bakhri, Ph.D., for his patience in taking the time to review and improve this manuscript. This research work was financially supported by the
Ministry of Research, Technology and Higher Education, Republic of Indonesia through INSINAS-Flagship 2019 Grant.

\section{References}

1. International Energy Agency. (2008). Energy technology prospectives: Scenario 7 strategies to 2050. Technical report. OECD/IEA, France.

2. Generation IV International Forum (GIF). (2014). Technology Roadmap Update for Generation IV Nuclear Energy Systems. OECD Nuclear Energy Agency.

3. Frima, L. L. W. (2013). Burnup in a molten salt fast reactor. Master Thesis. Department of Radiation Science and Technology, Faculty of Applied Sciences, Delft University of Technology. Available from https://d1rkab7tlqy5f1.cloudfront.net/TNW/ Afdelingen/Radiation\%20Science\%20and\%20Technology/Research\%20Groups/RPNM/Publications/ MSc_Lodewijk_Frima.pdf.

4. Graafland, C. (2014). Modeling and analysis of a depressurized loss of forced cooling event in a thorium fueled high temperature reactor. Bachelor Thesis. Department Radiation Science \& Technology, Faculty of Applied Sciences, Delft University of Technology. Available from https://d1rkab7tlqy5f1.cloudfront.net/ TNW/Afdelingen/Radiation $\% 20$ Science $\% 20$ and $\% 20$ Technology/Research\%20Groups/RPNM/Publications/BSc_Chris_Graafland.pdf.

5. Burns, J. R. (2015). Reactivity control of a PWR $19 \times 19$ uranium silicide fuel assembly. M. Sc. Thesis. Georgia Institute of Technology. Available from https://smartech. gatech.edu/bitstream/handle/1853/53975/BURNSTHESIS-2015.pdf? sequence $=1$ \&isAllowed $=y$.

6. Liu, S., Li, Z., Wang, K., Cheng, Q., \& She, D. (2018). Random geometry capability in RMC code for explicit analysis of polytype particle/pebble and applications to HTR-10 benchmark. Ann. Nucl. Energy, 111, 41-49.

7. Goorley, J. T., James, M. R., Booth, T. E., Brown, F. B., Bull, J. S., Cox, L. J., Durkee, J. W. Jr., Elson, J. S., Fensin, M. L., Forster, R., A. III, Hendricks, J. 
S., Hughes, H. G. III, Joghns, R. C., Kiedrowski, B. C., Martz, R. L., Mashnik, S. G., McKinney, G. W., Pelowitz, D. B., Prael, R. E., Sweezy, J. E., Waters, L. S., Wilcox, T., \& Zukaitis, A. J. (2013). Initial MCNP6 release overview - MCNP6 version 1.0. Los Alamos National Laboratory. (LA-UR-13-22934). DOI: 10.2172/1086758. Available from https:// permalink.lanl.gov/object/tr?what=info:lanl-repo/ lareport/LA-UR-13-22934.

8. Chadwick, M. B., Obložinský, P., Herman, M., Greene, N., McKnight, R., Smith, D., Young, P., MacFarlane, R., Hale, G., Frankle, S., Kahler, A. C., Kawano, T., Little, R., Madland, D., Moller, P., Mosteller, R., Page, P., Talou, P., Trellue, H., \& van der Marck, S. (2006). ENDF/B-VII: Next Generation Evaluated Nuclear Data Library for Nuclear Science and Technology. Nucl. Data Sheets, 107(12), 2931-3060.

9. International Atomic Energy Agency. (2013). Evaluation of high temperature gas-cooled reactor performance: Benchmark analysis related to initial testing of the HTTR and HTR10. Vienna, Austria: IAEA. (IAEA-TECDOC-1382).

10. Halla-aho, L. (2014). Development of an HTR-10 model in the SERPENT Reactor Physics Code. Unpublished Master's Thesis. Lappeenranta University of Technology, Finland.

11. Setiadipura, T., Irwanto, D., \& Zuhair. (2015). Preliminary neutronic design of high burnup OTTO cycle pebble bed reactor. Atom Indonesia, 41(1), 7-15.

12. Hosseini, S. A., \& Athari-Allaf, M. (2016). Effects of the wallpaper fuel design on the neutronic behavior of the HTR-10. Kerntechnik, 81(6), 627-633.

13. Zuhair., Suwoto., Setiadipura, T., \& Su'ud, Z. (2017). The effects of applying silicon carbide coating on core reactivity of pebble-bed HTR in water ingress accident. Kerntechnik, 82(1), 92-97. http://dx.doi. org/10.3139/124.110628.

14. Zuhair., Suwoto, S., \& Supriatna, P. (2012). Studi model heksagonal MCNP5 dalam perhitungan benchmark fisika teras HTR-10. Jurnal Matematika dan Sains, 17(2), 61-70.
15. Zuhair., \& Suwoto. (2015). Analisis efek kecelakaan water ingress terhadap reaktivitas doppler teras RGTT200K. Jurnal Teknologi Reaktor Nuklir TRI DASA MEGA, 17(1), 31-40. http://dx.doi. org/10.17146/tdm.2015.17.1.2238.

16. Zuhair., Suwoto., \& Yazid, P. I. (2013). Investigasi parameter bahan bakar pebble dalam perhitungan teras thorium RGTT200K. Jurnal Sains dan Teknologi Nuklir Indonesia, 14(2), 65-78.

17. Zuhair., Suwoto., Setiadipura, T., Bakhri, S., \& Sunaryo, G. R. (2018). Study on characteristic of temperature coefficient of reactivity for plutonium core of pebbled bed reactor. J. Phys.-Conf. Series, 962(1), 012058.

18. Suwoto., Adrial, H., Hamzah, A., Zuhair., Bakhri, S., \& Sunaryo, G. R. (2018). Neutron dose rate analysis on HTGR-10 reactor using Monte Carlo code. J. Phys.Conf. Series, 962(1), 012029.

19. Lebenhalt, J. L. (2001). MCNP4B modeling of pebblebed reactors. M.Sc. Thesis. Department of Nuclear Engineering, Massachusetts Institute of Technology. Available from https://web.mit.edu/pebble-bed/papers1_files/MCNP4B\%20Modeling.pdf.

20. Rosales, J., Munoz, A., Garcia, C., Garcia, L., Brayner, C., Perez, J., \& Abanades, A. (2014). Computational model for the neutronic simulation of pebble bed reactor's core using MCNPX. Int. J. Nucl. Energy, 2014, article ID 279073. http://dx.doi. org/10.1155/2014/279073.

21. Zuhair., Suwoto., Yazid, P. I., \& Pane, J. S. (2016). Studi model benchmark MCNP6 dalam perhitungan reaktivitas batang kendali HTR-10. GANENDRA Majalah IPTEK Nuklir, 19(2), 95-103. http://dx.doi. org/10.17146/gnd.2016.19.2.2880.

22. Hosking, G., \& Newton, T. D. (2005). Proposed benchmark specification for an HTR fuelled with reactor grade plutonium. Nuclear Energy Agency, Nuclear Science Committee. (NEW/NSC/ DOC(2003)22). 